\title{
The Performance of Fundamental Indexes: An Application on Istanbul ${ }^{*}$
}

\section{Temel Değerlere Dayalı Endekslerin Performansı: Borsa Istanbul Üzerine Bir Uygulama}

\author{
Habib KÜÇÜKŞAHIN ${ }^{1}$ \\ Ender COŞKUN²
}

https://orcid.org/0000-0003-2967-9814

https://orcid.org/0000-0003-2833-4363

\section{ABSTRACT}

In this study, the performance of the indexes constructed via fundamental values which are among the alternative indexing strategies, and the performance of the capitalization-weighted BIST 100 index are compared. The assets, sales, book value, operating profit and net profit figures in the financial statements are used to construct the index/portfolio according to the fundamental data. In addition to the indexes based on these data, a composite index and an equally-weighted index were also created. The returns of these indices were compared with the performance of the BIST 100 capitalization-weighted index through various portfolio performance measures. Among the indexes constructed through the fundamental values, the assets, book value, operating profit, net profit, and the indexes created by the 5 -year averages of these fundamental variables yield higher returns in the long term than BIST 100 capitalization-weighted index and this excess return is statistically significant. This result was supported by the analyses using the Capital Asset Pricing Model (CAPM) and the Fama-French three factor model. It was concluded that the indexes (except index created in accordance with the assets) had significant positive alpha coefficients. The results show that fundamental indexing strategies can be considered as an important investment alternative for the investors and that these strategies can create value in the long term.

Keywords: Smart Beta, Fundamental Indexation, Index Construction, Capitalization Weighted Index, Borsa Istanbul, Fundamental Weighted Index Performance, Composite Index

JEL Codes: C32, G11, G12

\section{ÖZET}

Çalışmamızda alternatif endeks oluşturma stratejilerinden temel değerlere göre oluşturulan endekslerin performansı ile kapitalizasyon ağırıklı BIST 100 endeksinin performansı karşılaştırılmıştır. Temel verilere göre endeks/ portföy oluşturmak amacıyla finansal tablolarda yer alan aktif, satış, defter değeri, faaliyet karı ve net kar rakamları kullanılmıştır. Bu verilere dayalı olarak oluşturulan endekslere ilave olarak kompozit endeks ve eşit ağırlıklı endeks de oluşturulmuştur. Oluşturulan endekslerin getirileri çeşitli portföy performans ölçütleri aracılığı ile BIST 100 kapitalizasyon ağırlıklı endeksin performansıyla karşılaştırılmıştır. Temel değerlere göre oluşturulan endekslerden aktif, defter değeri, faaliyet karı, net kar, ve bu temel değişkenlerin 5 yıllık ortalamalarıyla oluşturulan endekslerin uzun dönemde BIST 100 kapitalizasyon ağırıklı endeksden daha yüksek getiri sağladığı ve bu aşırı getirinin istatistiksel olarak anlamlı olduğu tespit edilmiştir. Bu sonuç Sermaye Varlık Fiyatlama Modeli (SVFM) ve Fama-French üç faktör model kullanılarak yapılan analizlerle de desteklenmiştir. Oluşturulan endekslerin (aktife göre oluşturulan endeks hariç) anlamlı pozitif alfa katsayılarına sahip olduğu sonucuna ulaşılmıştır. Elde edilen sonuçlar, temel değerlere göre endeks oluşturma stratejilerinin yatırımcılar açısından önemli bir yatırım alternatifi olarak dikkate alınabileceğini ve uzun dönemde bu stratejilerin değer yaratabileceğini göstermektedir.

Anahtar kelimeler: Gelişmiş Beta, Temel Değerlere Dayalı Endeks, Endeks Oluşturma, Kapitalizasyon Ağırlıklı Endeks, Borsa İstanbul Temel Değerlere Dayalı Endeks Performansı. Kompozit Endeks

\footnotetext{
" This article composed out of master thesis of Habib KÜçÜKŞAHIN

${ }^{1}$ Res. Asst., Pamukkale University, Faculty of Economics and Administrative Sciences, Department of Business Administration, hkucuksahin@pau.edu.tr.

${ }^{2}$ Assoc. Prof., Pamukkale University, Faculty of Economics and Administrative Sciences, Department of Business Administration,enderc@pau.edu.tr
} 


\section{Introduction}

The concept of risk has started to take place as a significant determinant in portfolio construction with the Modern Portfolio Theory (MPT), foundations of which were laid by Markowitz (1952). Accordingly, the interactions between stocks have become a driver in creating portfolios of lowered risks. Sharpe (1964), by incorporating risk-free assets into the investment opportunity set, has established the Capital Asset Pricing Model (CAPM), introduced beta as a risk measure to replace standard deviation. The beta coefficient used in the risk measurement for stocks rests upon the relationship between stock and market returns and measures the sensitivity of stock to the market index/ portfolio. CAPM asserts that returns of each stock can be explained by the market index due to the existence of a meaningful relationship between each stock traded in the market and the market portfolio. The market index postulated by CAPM is a capitalization-weighted index (Haugen and Baker, 1991; Hsu, 2004) and it is not possible to obtain returns in excess of this cap-weighted index used to measure the return of the market portfolio or get significant alpha coefficients (Ross, 1977). Cap-weighted indexes, in this respect, have been the most important indicator in passive investment strategies and beta measurements for a long time, moreover, they are used as a benchmark in assessing performances of fund managers in charge of actively managed portfolios (Podkaminer, 2015; Meziani, 2014). Positive alpha, which is attributed to the talents of the portfolio manager, has turned out to be an indicator of the manager's contribution to the portfolio's overall return via his decisions pertaining to portfolio composition. Later, it has been shown that positive alpha can also be attained by reconstructing indexes on simple rules, in contrast to ideas which assert positive alpha is only made possible with the portfolio manager's skills (Hsu, 2004; Arnott, 2005). In other words, rather than the proclaimed market cap-weighted index, one can obtain positive alpha with new indexes based on different rules. A weighting strategy other than the well-established one employing capitalization will lead to positive alpha without incurring any additional cost such as skilled analysts to be employed for active portfolio management, data gathering systems and software packages (Stotz et al., 2010; Basu and Forbes, 2014).

The proliferation of various alternative indexing strategies and their relatively better performances with respect to the conventional capital-weighting scheme has provoked new debates and resulted in shifting of investors' attention to such index compositions (Amenc et al., 2013; Meziani, 2014). These alternative strategies are collectively expressed as smart beta, which can be defined as constructing indexes on factors other than market caps in terms of the weighting mechanism (Roncalli, 2014). The outstanding goal of the smart beta strategy is constructing a portfolio, or an index which outperforms the one prescribed by CAPM and relies on a distinct weighting mechanism than this benchmark, i.e. market portfolio weighted by relative caps (Almahdi, 2015; Kahn and Lemmon, 2014). Moreover, resembling both active and passive portfolio management strategies, smart beta is an index construction strategy utilizing these two strategies to some extent (Bruce and Levy, 2014). On the other hand, its exclusion of buy-and-hold strategy, readjustment of factor induced weights, the irrelevance of market equilibrium and overall objective for excess return make the strategy comparable to active management strategy (Blitz and Swinkels, 2008).

Alternative index/portfolio development strategies, namely smart beta strategies as explained above, offer various choices in terms of investors' priorities towards risk or return. By following the framework implied by smart beta strategy, simple strategies such as equally-weighted investment strategy which is more convenient than its substitute employing market-cap weighting, risk-based strategy which puts more weights to low-risk stocks and return-focused strategy which takes fundamentals like stocks' book value, firms' sales, asset and dividend figures into account can also be implemented (Maillard et al., 2009; Podkaminer, 2015).

Developing indexes by smart beta strategy has some advantages over cap-weighted index construction. The most important among these is the extended opportunity to obtain returns higher than the market return (Blitz and Swinkels, 2008; Meziani, 2014), which becomes more apparent in the long run (Amenc et al., 2015). In addition, Podkaminer (2015) and Malkiel (2014) assert that alternative indexing strategies have lower costs. In a wider perspective, Arnott and Kose (2014) argue that advanced beta strategies achieve positive alpha as demanded by an active investment strategy through portfolios with a high degree of diversification, but at a far lower cost than incurred by such active strategy. Cap-weighted indexes typically give more weights to highly valued firms, thereby causing concentration to some sectors. This tendency may not be as common in smart beta indexes or portfolios as observed in cap-weighted 
indexes (Cazalet et al., 2013). Hence, concentration problem is less likely to occur in indexes/portfolios which are not weighted solely on a capitalization basis; accordingly, enhanced diversification benefits can be obtained. Since higher weights to high priced stocks are incorporated in cap-weighted indexes, they result in more losses due to markets' tendency towards mean-reversion in the long run (Hsu, 2014). In contrast, losses arising from a smart beta strategy are limited during mean-reversion periods, thanks to a lowered concentration of high-cap stocks. Developing indexes through a smart beta strategy has additional advantage pertaining to portfolio risk. Alternative indexing strategies are at lower or equivalent risk levels, but higher returns compared with the benchmark portfolio (Arnott et al., 2005). As a matter of fact, Cazalet et al. (2013) contend that betas based on cap-weighted indexes are higher than they should be. Therefore, an index weighted per fundamental data would be less volatile and likely to provide higher returns. The Higher degree of diversification within smart beta indexes emerges as a significant factor in curtailing total risk.

On the contrary, smart beta developing strategies pose some drawbacks depending on the method chosen. A typical problem might be reduced liquidity in equal-weighted index development strategy compared with cap-weighted one since weights for low-cap firms are taken the same as big-sized ones therein (Amenc et al., 2015). In general, alternative indexes might be less liquid and readjustment of weights would result in increased costs (Arnott et al., 2005). The other drawback of smart beta strategies appears in bull markets. As the climate is stimulating for markets and investors diverge from rationality, stocks tend to be increasingly overvalued, hence the weights of high-cap firms rise in cap-weighted indexes. That is why these indexes lead to more returns in bull markets due to the increased share of big companies in their compositions (Arnott et al., 2008). It should also be noted that studies testing the validity of views which argue smart beta strategies yield more returns than cap-weighted indexes rely on past data (Amenc et al., 2015).

Low volatility; high liquidity; equal-weighted and fundamental indexes can be considered among the indexes alternative to the market index (portfolio). Low-risk firms get higher weights in a minimum volatility investment strategy to attain the objective, that is, minimizing the overall index risk (Denoiseux, 2014). Following this strategy portfolios of lower risk as compared to the market-cap index are constructed and these are more favorable for risk-sensitive investors (Marchioni et al., 2015). In addition to lowered risks, returns of stocks with minimum volatilities might be higher than those with higher volatilities. In conformity with this assertion, Blitz and Van Vliet (2007) reported that stocks of low volatility yield more risk-adjusted returns than those with higher volatility. Furthermore, Marchioni et al. (2015) has shown stocks with low volatility and high-quality, where quality is evaluated in terms of trading volume and liquidity, outperforms high volatility and low-quality stocks. On the other hand, Hsu et al. (2015) and Denoiseux, (2014) claim minimum volatility indexes might have lower returns, moreover, tracking error in this strategy might increase, consequently the strategy would be less preferred by investors who take tracking error into account in their decisions. As also argued by Amenc (2013), these indexes might lead to an increased concentration in some sectors, members of which are the big size and high value firms.

High liquidity indexes constitute another group among smart beta strategies. Principally these indexes attach higher weights to high liquid stocks, but some other factors can also be considered in indexation as well. By choosing indexes which include high liquid securities, an investor demands more diversification benefits compared to market-cap indexes (Amenc et al., 2013). Allocation of stocks in high liquidity indexes can be accomplished in various ways depending on the risk/return preferences of the investor. High liquidity is the common attribute in the opportunity set; choosing securities with maximum decorrelation in between or those with maximum deconcentration (in terms of sector, similar firms) or alternatively, those with higher Sharpe ratios are some indexation methods within this smart beta strategy (Amenc, 2013).

Among smart beta strategies the most widely used smart beta index/portfolio construction strategy employs equal weighting method, which is the simplest one to apply (Podkaminer, 2015; Marchioni, 2015). In this strategy, stocks contained in the investment opportunity set, get the same weights (Malkiel, 2014). Equal-weighted indexes are mostly preferred by risk-neutral investors; risk and return characteristics are ignored in weighting methodology (Amenc, 2013). These indexes generally have higher returns than cap-weighted indexes (Hsu et al., 2015). Plyakha et al. (2012) and Montier (2013) have evidenced this fact by reporting higher returns for equal-weighted indexes. Nevertheless, lower liquidity, higher risk levels, and 
increased volatility despite a low degree of concentration with respect to cap-weighted indexes can be listed among the drawbacks of equally-weighted indexation strategy (Cazalet, 2013).

The fundamental index strategy, which is the main topic of our paper, makes use of metrics derived from financial statements, such as sales, operating profit, revenues, net profit, the number of employees, dividends paid, book value, stock repurchases, total assets, etc. in index weighting methodology. The performances of portfolios developed by these fundamental measures have been examined in various papers. Hsu (2004), Arnott et al. (2005) and Blitz and Swinkels (2008) are some examples in this domain. The suggestion to take basic economic variables, such as book value, sales, profit instead of market-caps as weighting factors, makes fundamental index strategy a reasonable alternative. Proponents of this strategy criticize cap-weighted indexes since they overweight excessively high valued stocks and underweight those valued far below their intrinsic values (Blitz and Swinkels, 2008). Investment strategies relying on these data have recently been popular as an alternative to market-cap indexes. The most important feature of such a smart beta strategy developed per fundamental analysis is the possibility of setting and revising portfolio weightings upon accounting data (Forbes and Basu, 2011).

Among the superior properties of fundamental indexes, or portfolios over other smart beta strategies, is their prioritization of high liquid stocks in weightings, just like cap-weighted indexes. In this respect, high liquidity and high capacity advantages of cap-weighted indexes are preserved in indexes based on fundamental data (Arnott et al., 2005). Moreover, indexes weighted in accordance with accounting data overcome the value related bias in cap-weighted indexation, i.e. high-valued stocks receive more weights vice versa (Arnott et al., 2005; Hsu and Campollo, 2006; Blitz and Swinkels, 2008). Hence, this approach attempts to propose a more realistic measurement by associating stocks' intrinsic values with firms' accounting data (Forbes and Basu, 2011). Fundamental indexation allows for the integration of more concrete data in the process, hence curtailment index volatility (Hsu and Campollo, 2006; Amenc et al., 2015).

The most outstanding disadvantage of fundamental indexation as compared with cap-weighting indexes is the probable additional costs related to re-weightings of stocks (Arnott et al., 2005). In addition to this disadvantage, higher weighting for higher valued stocks, which is a major problem in cap-weighted indexes might also be likely to occur (Podkaminer, 2015). Comparatively this disadvantage does not pose a problem since higher returns obtained by fundamental indexation strategy at the same risk levels make the strategy attractive for investors (Hsu 2004; Treynor 2005).

We can argue that the views advocated mainly for US and European markets in favor of fundamental indexation strategy in terms of higher returns than cap-weighted indexes, even probably at lowered risks in some cases, are likely to have more significant implications for emerging markets as well. This is because high-priced stocks have more relative weights in cap-weighted indexes, resulting in losses due to mean-reversion in the long-term (Hsu, 2014). Such a case is more likely to be apparent when the market is in an inefficient state. Therefore, this fact should be taken into consideration in more depth in emerging markets. Our main research question is closely related to this assertion: Can we get more returns through fundamental indexes in Borsa Istanbul, which is among emerging markets? No extensive research on Turkish markets has yet been conducted. However, two comparative research papers focusing on several countries contain some findings for Turkish markets. The first one by Walkshausl and Lobe (2010) examines performances of composite indexes in developed and emerging markets. The alpha coefficient for Turkey in this study is not found to be significant. Indexes based on earnings and dividends are found to generate significant alpha in the other study by Miziolek and Zaremba (2016) which analyses markets in Turkey, Poland, and Russia. Excess returns have not been examined in both papers. In this respect, we aim to make a contribution to literature. In this paper, indexes developed upon sales, total assets, book value, operating profit, and net profit are compared with cap-weighted indexes and tested for probable long-term abnormal returns and risk-adjusted returns. The following section overviews the past research on performances of fundamental indexes. The third section puts forth the index development methodology and compares returns of developed indexes with the cap-weighted one taking risk factors into account.

\section{Literature Review}

We note that research on the performances of portfolios developed per fundamental variables is concentrated in US and European markets. The papers on fundamental indexes we shall be reviewing are Arnott et al. (2005), Hsu and Campollo (2006), Arnott 
and West (2006), which are directed at US markets and Hemminki and Puttonen (2008), Hansson and Vikström (2010) are those towards European markets. In general, several indexes have been developed and to this end, various fundamental variables reflecting firms' core financial indicators in profit, sales, and size domains have been used in each research study. However, indexes developed upon asset, profit, revenue, dividend and equity are more heavily investigated. The variables and performances of portfolios developed upon these are summarized in Table 1. Arnott et al. (2005), for instance, has used net profit, dividends, total revenue, book value and personnel number as variables for indexation; Hsu and Campollo (2006), Arnott and West (2006), Hemminki and Puttonen (2008), Mcquarrie (2008) and Blitz et al. (2010) have based their portfolios on dividends, total sales, cash flow, and book value. Net profit variable has also been considered by Hansson and Vikström (2010), Hsieh et al. (2012) and Engel (2014). As can be deduced from Table 1, book value and total sales variables are the metrics taken by most of the studies. Additional variables are also employed by various researchers in composing their portfolios, e.g. Branch and Cai (2010) used book value per share in addition to total book value and research and development expenses in indexation, Francis et al. (2010) considered stock repurchases, Basu and Forbes (2014), Naylor and Dai (2016) regarded the number of shares traded in weight determination for their indexes. Besides these fundamental variables which have been taken into account by most of the studies, composite, e.g. Hsu and Campollo (2006), Arnott and West (2006); Stotz et al. (2010) and equal-weighted indexes, e.g. Francis et al. (2010), Chen et al. (2015) have also been developed.

Performances of developed indexes have been compared with the cap-weighted index by using various measures. Some papers base their comparisons on the cap-weighted portfolio's excess return, and its corresponding Sharpe ratio (McQuarrie, 2008; Kaiser, 2014; Ballatti, 2016). Tracking error has also been used as a performance indicator in some, e.g. Hsu et al. (2010); Fisher et al. (2015). Moreover, Mar et al. (2007), Walkshausl and Lobe (2010) have tested whether positive and significant alpha with respect to CAPM, three factor and four factor models has been obtained through fundamental indexes.

In Arnott et al. (2005) six indexes based on fundamental measures and additionally a composite index with equal weights of these each have been composed and their performances are compared with the cap-weighted index, S\&P 500. Readjustment period for the developed indexes has been set to be one year, for book value and personnel number annual averages are taken whereas sales, gross dividends, cash flow, and total revenues are averaged over five years in index construction. The Sales-based index has been found to yield the highest, and this has been estimated to be $2.38 \%$ higher than the S\&P 500 return annually. The mean annual abnormal returns on all indexes have been found to be statistically significant, as can also be seen in Table 1. Similar studies for the US have been conducted by Hsu and Campollo (2006), Arnott and West (2006), Blitz et al. (2010) and Stotz et al. (2010) taking cash flow, sales, dividends, and book value data. Hsu and Campollo (2006) developed separate indexes for US firms in the top 1000 and those listed in the S\&P 500 in their research covering the period 1962-2004. Taking Russel 1000 index as the benchmark for comparison they have reported nearly $2 \%$ more returns for the composite index, which they have constructed based on fundamental data, than this benchmark on average and determined that this abnormal return is statistically significant. Indexes developed have still been found to return more than the cap-weighted index, even transaction costs are taken into account. Likewise, Arnott and West (2006) have constructed fundamental indexes, and additionally, a composite index for the period 19622005 with the firms listed in Russell 1000 and Russell 2000. This study has found approximately $2.4 \%$ more annual returns on average than the cap-weighted index for Russell 1000 can be obtained with the index based on sales, while all abnormal returns reached have been found to be statistically significant. Blitz et al. (2010) analyzed the top 1000 firms in terms of capitalization and compared the performances of a fundamentally developed composite index with FTSE/RAFI. This analysis covers the period 1991-2009 and portfolios have been readjusted once in a year, however separate indexes have been formed for each quarter to find the highest performing index on time (quarter) dimension. The result declares the $1.84 \%$ more returns annually on average for the index constructed per fundamental variables on equal weighting basis, but no remark has been made on its statistical significance. Stotz et al. (2010) have developed indexes for companies listed in Dow Jones Stoxx 600 index and compared their performances against the cap-weighted index for the period 1993-2007. Among the fundamental indexes, the one weighted on sales has outperformed the others, which are similarly based on some other fundamental data. 
This best return has been found to be $13.8 \%$ per annum on average. Sales based index has also been estimated to return $2.23 \%$ higher than the cap-weighted one on an annual basis.

In another study by Jun and Malkiel (2008), book value, sales, dividends, and earnings were considered. Performances of indexes based on the fundamentals have been assessed against cap-weighted S\&P 500 index and an additional index developed for this purpose. This index is composed of firms all with equal weights; low-cap firms and firms listed in Russell 1000 index, each having a $1 / 3$ share in the overall composition. Indexes developed by the aforementioned fundamental variables are annually revised with respect to member weights. The average annual difference between returns of the highest yielding index based on accounting data and the cap-weighted, S\&P 500 index is found to be $8.94 \%$, whereas the difference becomes $1.11 \%$ when the S\&P 500 is replaced with the additional index. Nevertheless, no reference as to the statistical significance of this outcome has been made.

Table 1: Fundamental Variables Used in Selected Research Papers

\begin{tabular}{|c|c|c|c|c|c|c|c|c|c|c|c|c|c|c|c|c|}
\hline & NP & OI & D & TS & TR & OP & CF & $\begin{array}{l}0 \\
\text { CF }\end{array}$ & TA & BV & NE & RD & SR & ST & CM & ОTH \\
\hline Arnott et al. (2005) & $\mathbf{H}^{*}$ & & $\mathbf{H}^{*}$ & $\mathbf{H}^{*}$ & $\mathbf{H}^{*}$ & & & & & $\mathbf{H}^{*}$ & $\mathbf{H}^{*}$ & & & & $\mathbf{H}^{*}$ & \\
\hline Hsu \& Campollo (2006) & & & $\mathbf{H}$ & $\mathbf{H}$ & & & $\mathbf{H}$ & & & $\mathbf{H}$ & & & & & $\mathbf{H}^{*}$ & \\
\hline Arnott \& West (2006) & & & $\mathbf{H}^{*}$ & $\mathbf{H}^{*}$ & & & $\mathbf{H}^{*}$ & & & $\mathbf{H}^{*}$ & & & & & $\mathrm{H}^{*}$ & \\
\hline Estrada (2007) & & & $\mathbf{H}$ & & & & & & & & & & & & & \\
\hline Mar et al. (2007) & & & & & $\mathbf{H}^{*}$ & & & $\mathbf{H}^{*}$ & & $\mathbf{H}^{*}$ & & & & & $\mathbf{H}^{*}$ & \\
\hline Hemminki \& Puttonen(2008) & & & $\mathbf{H}^{*}$ & $\mathbf{H}$ & & & H & & & $\mathbf{H}^{*}$ & & & & & $\mathbf{H}^{*}$ & \\
\hline Jun \& Malkiel (2008) & H & & $\mathbf{H}$ & $\mathbf{H}$ & & & & & & $\mathbf{H}$ & & & & & H & \\
\hline Houwer \& Plantinga (2009) & & $\mathbf{H}^{*}$ & $\mathbf{H}^{*}$ & $\mathbf{H}^{*}$ & & & & & & $\mathbf{H}^{*}$ & & & & & $\mathbf{H}^{*}$ & \\
\hline Mihm \& Locarek-Junge (2009) & & & $\mathbf{H}^{*}$ & & $\mathbf{H}^{*}$ & & & & $\mathbf{H}^{*}$ & $\mathbf{H}^{*}$ & $\mathbf{H}^{*}$ & & & & - & \\
\hline Blitz et al. (2010) & & & $\mathbf{H}$ & $\mathbf{H}$ & & & H & & & $\mathbf{H}$ & & & & & H & \\
\hline Branch \& Cai (2010) & & & & $\mathbf{H}$ & & & H & & & $\mathbf{H}$ & & H & & & & $\mathbf{x}$ \\
\hline Francis et al. (2010) & & & $\mathbf{H}$ & $\mathbf{H}$ & $\mathbf{H}$ & & $\mathbf{H}$ & & $\mathbf{H}$ & $\mathbf{H}$ & H & & H & & & \\
\hline Hsu et al. (2010) & & & $\mathbf{H}$ & $\mathbf{H}$ & & & $\mathbf{H}$ & & & $\mathbf{H}$ & & & & & H & \\
\hline Stotz v.d. (2010) & & & $\mathbf{H}^{*}$ & $\mathbf{H}^{*}$ & & & $\mathbf{H}^{*}$ & & & $\mathbf{H}^{*}$ & & & & & $\mathbf{H}^{*}$ & \\
\hline Walkshausl \& Lobe (2010) & & & $\mathbf{H}$ & $\mathbf{H}$ & $\mathbf{H}$ & & $\mathbf{H}$ & & & $\mathbf{H}$ & H & & & & H & \\
\hline Ferreira \& Krige (2011) & & & $\mathbf{H}$ & $\mathbf{H}$ & & & $\mathbf{H}$ & & & $\mathbf{H}$ & & & & & H & \\
\hline De Moor et al. (2012) & & & & $\mathbf{H}^{*}$ & & & $\mathbf{H}^{*}$ & & & $\mathbf{H}^{*}$ & & & & & & \\
\hline Hsieh (2013) & & & H & $\mathbf{H}^{*}$ & $\mathbf{H}$ & & & & & $\mathbf{H}$ & & & & & H & $\mathbf{x}$ \\
\hline Basu \& Forbes (2014) & & & $\mathbf{H}^{*}$ & $\mathbf{H}^{*}$ & & $\mathbf{H}^{*}$ & & & & $\mathbf{H}^{*}$ & $\mathbf{H}^{*}$ & & $\mathbf{H}^{*}$ & & $\mathbf{H}^{*}$ & \\
\hline Engel (2014) & H & & $\mathbf{H}$ & $\mathbf{H}$ & & & & & & $\mathbf{H}$ & & & & $\mathbf{H}$ & & \\
\hline Chen et al. (2015) & $\mathbf{H}^{*}$ & & $\mathbf{H}$ & H & $\mathbf{H}^{*}$ & & H & & & $\mathbf{H}$ & H & & & & H & \\
\hline Miziolek \& Zaremba (2016) & $\mathbf{H}^{*}$ & & $\mathbf{H}^{*}$ & $\mathbf{H}^{*}$ & & & - & & & $\mathbf{H}$ & & & & & & \\
\hline Balatti et al. (2016) & & & H & $\mathbf{H}$ & & & H & & & H & & & & & H & $\mathbf{x}$ \\
\hline Naylor \& Dai(2016) & & & H & $\mathbf{H}$ & & & H & & & H & & & & & & \\
\hline
\end{tabular}

$H^{*}$ : Statistically significant excess returns, $H$ : No information on significance of excess returns, $X$ : Studies that used other fundamental variables NP: Net profit, Ol: Operating Income, D: Dividends, TS: Total sales, TR: Total revenues, OR: Operating profits, CF: Cash flow, OCF: Operating cash flow, TA: Total assets, BV: Book value, P: Number of employees, RD: Research \& Development expenses, SR: Share repurchases, ST: Number of shares traded, CM: Composite index (Index developed with all fundamental data, each having equal weights), OTH: Others 
As can be observed from Table 1, Chen et al. (2015) have composed indexes from shares of firms listed in DJIA and Russell 1000 where the indexes have been formulated based on 7 different fundamental variables. The performances of these indexes were compared with the cap-weighted indexes for the time period 1962-2009. Though fundamental indexes made up of DJIA firms have returns in excess of the cap-weighted index, excess returns of the composite index and fundamental indexes based on book value, cash flow, dividends, sales, net income, and personnel number have been found to be statistically insignificant. Apart from book value and dividend indexes, fundamental indexes from the Russell 1000 firms had excess returns at $10 \%$ significance level.

Such studies concerning the performance of portfolios/indexes based on fundamental variables have also been increasingly carried out further outside the US. Hemminki and Puttonen (2008), Ferreira and Krige (2011), Hansson and Vikström (2010), Engel (2014) and Mar et al. (2007), for instance, have reported important findings for various countries supporting higher returns of fundamental indexes. Hemminki and Puttonen (2008) have developed indexes for Euro Stoxx 500 companies and found the highest returning index is the dividend index with an average annual return of $2.91 \%$. They also determined that composite and book-value indexes have statistically significant excess returns. Ferreira and Krige (2011), in their study towards South African stock market, have found out that sales-based index has the highest return among all indexes they have formed, and this is $4.7 \%$ higher than the cap-weighted index returns on average. However, no conclusive remark has been made on the significance of this difference either. Engel (2014), on the other hand, has composed indexes based on fundamental data of the firms whose shares are traded in the Johannesburg stock market. Including the number of shares traded among the fundamental variables, this paper also investigates the effect of a number of firms in the index on index return. The result suggests that as the number of firms included in the index which is based on fundamental data, increases the risk-adjusted return of the corresponding index tends to rise.

Besides, some researches compare indexes between several countries. As a comprehensive example, in Estrada's (2007) paper separate indexes based on dividend per share for 16 countries have been developed and their performances have been evaluated with respect to the corresponding cap-weighted in- dex. When the cost of indexation is ignored, indexes weighted by dividend per share variable are found to yield 1.9\% higher returns than the cap-weighted one on average. This difference drops to $1.7 \%$ in case the costs associated are accounted for. In another study, Naylor and Dai (2016) have composed indexes using fundamental data for the member firms of benchmark indexes in Brazil, China, Russia, and India. The variables employed are firms'book values, cash flows, total sales, and dividends. Indexes weighted on cash flow basis have the highest returns for Brazil, India, and Russia. Other fundamental indexes outperform the benchmark index as well. However, among the indexes developed for China, the dividend-weighted index has been the best performer and the cash flow-based index has resulted in a lower return than the benchmark index.

All papers reviewed so far aim to identify if any excess return can be made with the developed indexes by direct comparison with the benchmark where the return assessments are based on the Sharpe ratio and tracking error. In addition to these, some studies make use of CAPM, three factor model and four factor model to find alpha as an alternative performance measure. In other words, excess returns that are adjusted for systematic risk have been tested for statistical significance (Stotz et al., 2010). Houwer and Plantinga (2009), Francis et al. (2010), Lajbcygier and Sojka (2015), Miziolek and Zaremba (2016), Mar et al. (2007) and Walkshausl and Lobe (2010) are among the researches in this group.

Houwer and Plantinga (2009) have further considered operating income in addition to book value, gross dividends and revenues in developing indexes from the firms listed in Dow Jones Stoxx 600. The result shows composite index has $2.42 \%$ higher annual return than a cap-weighted index on average, and monthly excess returns on all fundamental indexes are statistically significant. In a further analysis on risk-adjusted returns from all five indexes with respect to three factor model, positive and significant alphas have been reported except for the index based on book value. Francis et al. (2010) performed a similar study for the biggest 1000 US firms and developed various indexes on 5-year average total sales, total gross dividends, cash flows, total earnings together with the number of employees, stock repurchases, and total dividend pay-outs. Performances have been evaluated by alphas estimated through the four factor model. While indexes based on a total payout, repurchases, and earnings result in positive alphas, no statistically significant alpha obtained by other indexes. Hsu et al. (2010) have 
evaluated the performance of the composite index they have developed using sales, cash flow, book value, and dividends data of the firms operating in real estate businesses in the US against both FTSE NAREIT Composite $\mathrm{TR}$, a composite index which comprises real estate firms in US and Russell 1000 Index. The alpha coefficients for their index estimated through CAPM and four factor model have been reported to be positive and statistically significant. Branch and Cai (2010) have developed indexes for the firms in S\&P 500 index where they based this indexation process on sales, book value, cash flow variables and some additional variables which make this research different from the others, i.e. gross profit margin, research and development expenses, book value per share. By following the equallly-weighted method, a composite index based on all variables has also been constructed. Reweighting of indexes have been accomplished with two frequencies; monthly and annually. Among the annually reweighted indexes, gross profit margin-based index yielded the highest return. Cash flow-based index has been reported to have the best return performance for those which were monthly reweighted. All portfolios except for the research and development-based one output positive and significant alpha values with respect to CAPM and four factor model.

De Moor et al. (2012), on the other hand, have composed cap-weighted indexes themselves and compared performances of fundamental indexes against these. Depending on the changes in fundamental variables indexes have been reweighted on a monthly basis. This study, in which returns are also computed monthly has found out that book value-based index has the highest return which is $0.312 \%$ above the cap-weighted index's return on average and significant as well. Moreover, indexes constructed return positive and significant alpha coefficients estimated under the four factor model.

Hsieh (2013) has analyzed performances of fundamental indexes for the period 1996-2010 where the firms under study were members of the S\&P Emerging Large-Mid-Cap index. Index weighted by sales has provided the highest and significant excess return. Excess returns from all remaining indexes developed have not been found significant. Except for the best performing sales-based index, alpha values per three factor model of indexes are reported negative.

Mar et al. (2007) and Basu and Forbes (2014) have made similar studies on the Australian market. Mar et al. (2007) have chosen the Australian ASX 200 index as the benchmark and founded indexes based on fundamental data for the firms listed there. The research, where fundamental data has been averaged over 3 years, has found out that both individual indexes and the composite index have higher returns than the benchmark which is the cap weighted ASX 200 index. Jensen's alpha has also been reported significant. Basu and Forbes (2014), have shown that the fundamental index with the highest return outperforms the cap-weighted index by a $4.3 \%$ difference on average annually where they have constructed indexes using much more fundamental data with an analysis period, 19852010. Moreover, all excess returns reached have been statistically significant and their composite index has performed well with respect to CAPM, three factor and four factor model resulting in positive and significant alpha coefficients. Mihm and Locarek-Junge (2009) have developed fundamental indexes, each comprising 100 firms whose shares are traded in the German stock market for the period 1988-2007. The index with the highest return in this study has been determined to be the one based on total asset value while all indexes have been found to yield statistically significant abnormal returns. Furthermore, alpha values obtained through the Fama-French three factor model have been found to be significant for total assets, book value and dividend indexes. In another study for the UK market, Balatti et al. (2016) have composed composite revenue and composite dividend indexes using the variables; book value, cash flow, total sales, dividends, dividend payout ratio, dividend coverage ratio and earnings before interest, tax, depreciation and amortization (EBITDA) of the firms listed in FTSE 100 index for the period 1989-2014. Composite revenue index has been based on sales, EBITDA, and dividends sub-indexes on the equally-weighted method. The same arrangement has been applied to composite dividend index with the sub-indexes, dividends, dividend payout ratio, and dividend coverage ratio. Both composite indexes have been reported to output positive and statistically significant alpha coefficients.

Walkshausl and Lobe (2010) have developed indexes based on fundamental data of companies in 50 countries, 28 of which being in developed countries, 22 in developing markets, for the time period 19822008. The variables employed in indexation are book value, cash flow, dividends, total income, number of employees, and sales. Additionally, an index based on net payout data has also been constructed. Due to the variability of data indexes have been reweighted annually. Among these indexes for 50 countries, those 
based on accounting data for 4 countries have been found to be underperformers with respect to cap-weighted benchmarks. When risk-adjusted returns are taken into account, Sharpe ratios on 43 countries have been shown to be better than the Sharpe ratios on the corresponding benchmark indexes. Analyses in terms of CAPM and four factor model have turned out different results for different countries. Alpha coefficients of four factor model for composite indexes, for instance, have been confirmed a positive and significant for US, Canada, Germany, and France, however corresponding coefficients for Switzerland, Hungary and Turkey were reported as insignificant.

Another paper considering variations between countries is Miziolek and Zaremba (2016). They have constructed indexes based on fundamental data of the firms whose shares are traded in Polish, Russian and Turkish markets. 20-month moving averages of book value, earnings, sales, and dividends have been used in this formation. Performances of the indexes have been tested for the period 2002-2015. Fundamental indexes have been noticed to yield higher returns than corresponding cap-weighted indexes for Turkey and Poland. Indexes for Russia, on the other hand, have lower returns than those in Turkey and Poland. The final analysis on risk-adjusted returns for the 3 countries has shown that only the indexes based on sales and dividends yielded positive and significant alpha values.

$$
\mathrm{Wi}, \mathrm{t}=\frac{\mathrm{F}_{\mathrm{i}, \mathrm{T}-1}}{\sum_{i=1}^{\mathrm{n}} \mathrm{F}_{\mathrm{i}, \mathrm{T}-1}}
$$

$\mathrm{Wi}, \mathrm{t}=$ Weight of $\mathrm{i}^{\mathrm{th}}$ stock in the index constructed at the beginning of year $\mathrm{t}$

$\mathrm{F}_{\mathrm{i}, \mathrm{t}-1}=$ The value of the fundamental variable (eg. book value) for $\mathrm{i}^{\mathrm{th}}$ stock at the end of $\mathrm{t}-1$

$\sum_{i=1}^{n} F_{i, t-1}=$ Sum of values of fundamental variables for all firms at the end of $t-1$

$$
\sum_{i=1}^{\mathrm{n}} \mathrm{w}_{\mathrm{i}, \mathrm{t}}=1
$$

In addition to these indexes, a composite index has also been formed weighting all fundamental indexes equally following the method in Arnott et al. (2005), Stotz et al. (2010) and Hsu et al. (2010). It is postulated that when underlying weighting methods of single factor indexing and composite indexing are compared, composite indexes tend to reflect firms'intrinsic values

\section{Index Construction Methodology}

We have developed indexes which are alternatives to cap-weighted indexes using data for companies whose shares are traded in Borsa Istanbul. These indexes have been obtained using firms' fundamental data through weighting methodology and their performances are assessed with respect to the cap weighted index, namely Borsa Istanbul 100 index. The data for indexation consists of fundamental data derived from balance sheets and income statements of firms for the years 1997-2014, whereas indexes are composed for the period 2001-2015. Moore (AHM) (2005) is adopted as a fundamental indexation methodology in our paper. Hence, we use fundamental data in index weighting, and shares of stocks in an index are determined accordingly. There are various fundamental measures in indexation as also outlined in the previous section. The most outstanding of these, namely total assets, net sales, operating profit, and net profit are selected for our research. 5 different indexes have been developed which are based on asset size, net sales, operating profit, book value, and net profit by taking the previous year's ( $t-1$ ) figure in line with the AHM method. In order to curtail the effects of short-term volatility of the variables, 5 mean indexes are also composed where weights have been based on the most recent five-year averages of the same variables. The following formula is used in determining weights:
The methodology followed by Arnott, Hsu, and better (Stotz et al., 2010). The composite index has been developed with the following weighting formula, i.e. equal weights on 5 fundamental indexes:

$$
x_{i . t}^{c o m p}=\frac{x_{i, t}^{T A}+x_{i, t}^{S A L}+x_{i, t}^{O I}+x_{i, t}^{N I}+x_{i, t}^{B V}}{5}
$$


We have also composed an equal-weighted index which provides an alternative approach for performance evaluation. The firms are sorted by their market values, and the first 100 are determined for this purpose. All 100 firms with the highest values in the market are associated with the same weight, which is $1 / 100$.

Including the composite index which is made up of indexes based on asset size, net profit, net sales, operating revenue and book value in equal proportions, 12 portfolios are constructed per year for the whole 15 years and the portfolios are readjusted annually. The returns of these readjusted portfolios are compared with the cap-weighted BIST-100 index. Considering probable misstatements about personnel number, we diverge from AHM methodology by replacing this variable with asset size. Similarly, Houwer and Plantinga (2009), Mihm and Locarek-Junge (2009) have used asset size instead of personnel number. Indexes which take place in AHM methodology and are based on 5-year averages of total gross dividends are not constructed here since 100 stocks, i.e. the required number of stocks with this data are not available for most of the entire 15-year long data period. Following the method used in Branch and Cai (2010) and De Moor et al. (2012), companies which withdrew from the stock market or whose shares ceased to be traded due to noncompliance with their obligations during 1997-2015 are included in the indexation process for the years in which their shares were actively traded.

\section{Performance Evaluation}

The first evaluation is made comparing portfolio performances against the BIST 100 index to determine whether abnormal returns are statistically significant. Moreover, the Sharpe ratio, information ratio, and tracking error are estimated for evaluation purposes. The information ratio is calculated by dividing the difference in returns between the portfolio/index composed and the benchmark portfolio/index by the standard deviation of this difference. The formula for information ratio is given below:

$$
\begin{aligned}
& \text { Information Ratio }=\frac{\left(\mathrm{R}_{\mathrm{p}}-\mathrm{R}_{\mathrm{i}}\right)}{\mathrm{S}_{\mathrm{p}-\mathrm{i}}} \\
& \mathrm{R}_{\mathrm{p}}=\text { Portfolio return } \\
& \mathrm{R}_{\mathrm{i}}=\text { Return of index or benchmark portfolio } \\
& \mathrm{S}_{\mathrm{p}-\mathrm{i}}=\text { Tracking error }
\end{aligned}
$$

Information ratio, unlike the Sharpe ratio, reflects the riskiness of the portfolio or index with respect to the benchmark portfolio/index. Further, this ratio is a measure for investors to assess the portfolio manager's success. A higher information ratio than the benchmark's information ratio indicates that the portfolio manager is successful in his/her portfolio development.

Apart from making up the denominator term in information ratio, tracking error is an indicator as to the stability (consistency) of the index/portfolio constructed by the portfolio manager adopting an active trading strategy against the benchmark portfolio in terms of performance. It is defined as the standard deviation of the differences between portfolio returns and the benchmark returns (Frino and Gallagher, 2001). Contrary to the information ratio, minimized tracking error is favored. Lower tracking error leads to a higher information ratio, thus is a success criterion for the portfolio manager.

$$
\begin{aligned}
& \text { Tracking Error }\left(\mathrm{S}_{\mathrm{p}-\mathrm{i}}\right)=\sqrt{\frac{\sum_{j=1}^{n}\left(R_{p ; j}-R_{i ; j}\right)^{2}}{N}} \\
& \mathrm{~S}_{\mathrm{p}-\mathrm{i}}=\text { Tracking error } \\
& \mathrm{R}_{\mathrm{p} ; \mathrm{j}}=\text { Portfolio's return on day } \mathrm{j} \\
& \mathrm{R}_{\mathrm{i} ; \mathrm{j}}=\text { Return of index or benchmark portfolio on day } \mathrm{j}
\end{aligned}
$$

The significance of positive returns achieved by fundamental indexes which we have developed has also been tested in our research with respect to CAPM and Fama-French three factor model. The practical purpose of using CAPM and three factor model is to depict whether fundamental indexes have positive alpha coefficients. In case returns from these indexes have positive and significant alpha values when compared through these models, it can be concluded that they outperform the market portfolio. In other words, returns from the portfolios weighted by fundamental data cannot be fully explained by CAPM and three factor model and returns from such portfolios which are adjusted for systematic risk exceeds the cap-weighted index return. In order to review indexes developed from firms'fundamental data by factor analysis, we compute monthly returns covering the period 2006-2015, which has no missing value, to form our dataset. Then, the CAPM and the three factor model are used to explain these returns. Following Jensen (1967), the following regression model is set to account for index returns with CAPM (Basu and Forbes, 2014):

$$
R_{F t}-R_{f t}=\alpha_{f}+\beta i\left(R_{m t}-R_{f t}\right)+\varepsilon_{F t}
$$

In this model $R_{\mathrm{Ft}^{\prime}} R_{\mathrm{ft}} \mathrm{R}_{\mathrm{mt}}$ and $\mathrm{a}_{\mathrm{f}}$ denote each fundamental index's return, risk-free interest rate, cap-weighted index's return and the excess return which cannot be explained by CAPM respectively. The 
other term in the model, $B_{i}$ is the slope between excess return (Rmt - Rft) on BIST-100 index and excess return (RFt - Rft) of the index constructed by the fundamental data in firms' financial statements. Finally, $\varepsilon_{F t}$ denotes the model's error term. Further to estimating the CAPM model for each index, the three factor model is also fitted to account for excess return. three factor model proposed by Fama and French $(1993,1996)$ is presented in its mathematical form below:

$R_{F t}-R_{f t}=\alpha_{f}+\beta i\left(R_{m t}-R_{f t}\right)+\gamma_{F} . S M B_{t}+\delta_{F} . H M L+\varepsilon_{F t}$

$S M B$ in the equation is used to express the difference between returns of small-cap stocks and big-cap stocks while the same definition holds for HML between stocks with high book-to-market $(\mathrm{B} / \mathrm{M})$ ratios and low $\mathrm{B} / \mathrm{Ms}$. Unlike CAPM, the three-factor model suggests size and $B / M$ ratio have an effect in getting returns in excess of the market return. In this respect, the three factor model can provide some explanation for a positive alpha, which cannot be explained by CAPM.

In order to evaluate performances, the alpha coefficients by the CAPM and the three factor model are estimated with a monthly return series of indexes for the time period 2006-2015. The market index in the models is selected to be BIST-100 index and returns on one-year government bond are used as the risk-free rate. three factor model, on the other hand, is based on Fama and French's $(1993,1996)$ methodology. Having positive and significant alphas in models implies better performances on portfolios developed.

\section{Research Findings}

We discuss the outcome concerning the returns obtained through the AHM methodology and further the findings due to the comparison of these returns with the BIST-100 index. The index returns calculated are first benchmarked against the market portfolio, then evaluated within the scope of the Capital Asset Pricing Model and the three factor model.

\subsection{Comparison of Constructed Indexes with the Benchmark Index}

Annual returns for the period 2001-2015 of each portfolio constructed by using the companies' asset size, book value, net profit, operating profit, and sales revenue data, returns for the composite index formed using the averages of these portfolios, annual returns of the equal-weighted index, returns for the indexes based on 5-year averages of fundamental data and the cap-weighted index, namely BIST 100 return are comparatively shown in Table 2 . The excess returns of the fundamental indexes and the statistical tests concerning these are also reported in Table 3.

Examining Table 2 with these explanations in mind, we notice that while BIST 100 index has an average annual return of $22.1 \%$, all indexes weighted per fundamental data have higher returns than BIST 100. The best performing index among these fundamental indexes is the one weighted by asset size. Return on the index composed with asset size data turns out to be $27.4 \%$ per annum on average, the index based on net profit follows this with an average annual return of $27.3 \%$. Index based on sales, in this respect has the lowest return, i.e. $24.5 \%$. Similar findings have been observed concerning performances of the indexes constructed using the past 5-year average data. Among these indexes, those developed with respect to asset size and net profit criteria are the highest performers. On the other hand, the average annual holding period returns are $14.5 \%$ for BIST $100,19.3 \%$ for the index weighted by net profit and $18.7 \%$ for the one weighted by average net profit. While the index weighted by net profit is at the top in terms of performance, the index weighted by asset size follows this with an annual average holding period return of $18 \%$. In other words, the cumulative value of 100 TL invested in the BIST 100 index in 2001 reached 760 TL at the end of 2015; holding investment period the same, the same amount grows to $1405 \mathrm{TL}$ and $1195 \mathrm{TL}$ in case the investor prefers the index based on net profit and the index based on asset size, respectively. The amount to be reached would be 1202 TL for the composite index. However, when Table 2 is reviewed, it appears the risk of each index except for the equal-weighted one is higher than the risk of the BIST 100 index. When Sharpe ratios, which are calculated to account for this fact in terms of performance, are taken into account, indexes based on both annual and 5-year average fundamental data have greater Sharpe ratios than BIST 100 index has. This finding indicates marginal return per additional unit of risk taken is higher on fundamental indexes. Analysis of information ratios of the indexes shows the index formed with net profit data has the highest ratio whereas the one with the lowest ratio is the index based on sales. For the indexes composed with 5-year average data, the index based on operating profit has the highest information ratio. As expected, this index also has the lowest tracking error. 
Table 2: Annual Average Returns and Performance Summaries of Fundamental and Benchmark Indexes

\begin{tabular}{|c|c|c|c|c|c|c|c|c|c|c|c|c|c|}
\hline PERIOD & A & $\mathrm{S}$ & NP & OP & BV & COMP & EW & $\mathrm{AA}$ & AS & ANP & AOP & ABV & BIST \\
\hline 2001 & 607 & 0.428 & 0.633 & 0.612 & 0.586 & 0.573 & 0.474 & 0.598 & 0.372 & 0.621 & 0.593 & 0.574 & 0.460 \\
\hline 2002 & -0.225 & -0.211 & -0.154 & -0.157 & -0.184 & -0.186 & .049 & 0.222 & -0.226 & -0.172 & -0.173 & 179 & 0.248 \\
\hline 2003 & 0.975 & 0.723 & 0.815 & 0.764 & 0.861 & 0.828 & 0.575 & 0.944 & 0.693 & 0.777 & 0.817 & 0.833 & 0.796 \\
\hline 2004 & 0.380 & 0.223 & 0.458 & 0.290 & 0.373 & 45 & 0.358 & 0.432 & 0.242 & 0.498 & & 0.369 & .341 \\
\hline 2005 & 0.728 & 0.495 & 0.622 & 0.611 & 0.584 & 0.608 & 0.613 & 0.743 & 0.536 & 0.614 & 637 & .603 & 0.593 \\
\hline 2006 & -0.018 & 0.009 & 0.015 & 0.015 & 0.003 & 0.005 & 0.006 & -0.012 & 0.016 & & & 0.005 & -0.017 \\
\hline 2007 & 0.401 & 0.363 & 0.376 & 0.384 & 0.353 & 0.375 & 0.199 & 0.386 & 0.348 & 0.373 & .361 & 0.349 & 0.420 \\
\hline 2008 & -0.498 & -0.508 & -0.489 & -0.493 & -0.498 & & & & & & & & \\
\hline 2009 & & & & & & & & & & & & & \\
\hline 2010 & 0.282 & 0.384 & 0.306 & 0.311 & 0.303 & 0.317 & 0.454 & 0.284 & 0.394 & 0.311 & 0.3 & 0.303 & 0.249 \\
\hline 2011 & -0.279 & -0.196 & -0.221 & -0.216 & -0.229 & -0.228 & -0.165 & -0.2 & -0 . & -0. & -0. & -0 . & -0.223 \\
\hline & 0.666 & & & & & & & & & & & & 26 \\
\hline 2013 & -0.169 & -0.085 & -0.119 & -0.124 & -0.120 & -0.123 & -0.038 & & & & & & -0.133 \\
\hline 2014 & 0.301 & 0.305 & 0.266 & 0.316 & 0.301 & 0.298 & 0.292 & 0.307 & 19 & 0.277 & 2 & 0.307 & 0.264 \\
\hline 2015 & -0.171 & -0.066 & -0.135 & -0.156 & -0.142 & -0.134 & -0.015 & -0.170 & -0.062 & -0.145 & -0.156 & -0.140 & -0.163 \\
\hline 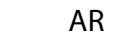 & & & & & & & & & & & & & 0.221 \\
\hline GR & 0.180 & 0.169 & 0.193 & 0.178 & 0.179 & 0.180 & 0.183 & & & & & & 0.145 \\
\hline EV & 95 & 1044 & 1405 & 1163 & 1175 & 1202 & 1245 & 1238 & 19 & 13 & 1259 & 1180 & 760 \\
\hline SD & 0.490 & & & & & & & & & & & & 0.424 \\
\hline & 0.560 & 0.553 & 0.609 & & & 0.580 & & & & & & & 0.521 \\
\hline & 0.367 & 0.382 & 0.431 & 0.409 & 0.397 & 0.400 & 0.467 & 0.372 & 0.372 & 0.426 & 0.418 & 0.400 & 0.341 \\
\hline $\mathrm{IR}_{(\mathrm{AR})}$ & 0.677 & 0.230 & 0.867 & 0.594 & 0.708 & 0.750 & 0.198 & 0.715 & 0.207 & 0.748 & 0.892 & 0.709 & \\
\hline $\mathrm{IR}_{(\mathrm{GR})}$ & 0.445 & 0.230 & 0.806 & 0.591 & 0.627 & 0.664 & 0.297 & 0.479 & 0.193 & 0.708 & 0.846 & 0.637 & 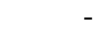 \\
\hline $\mathrm{TE}$ & 0.079 & 0.106 & 0.059 & 0.056 & 0.054 & 0.054 & 0.129 & 0.079 & 0.117 & 0.060 & 0.046 & 0.054 & - \\
\hline
\end{tabular}

The table reports the returns of the indexes/portfolios weighted on capitalizations ("BIST"), assets (" $\mathrm{A}$ "), book Value ("BV"), operating profit ("OP"), net profit ("NP"), sales ("S"), five-year average assets ("A $A$ "), five-year average book value ("ABV"), five-year average operating profits ("AOP"), fiveyear average net profits ("ANP"), five-year average sales ("AS"), and the equally-weighted index ("EW"), the composite index ("COMP").

AR: Annual Average Arithmetic Return, GR: Annual Average Geometric Return, EV: Ending Value of 100 TL at the end of 2015, SD: Standard Deviation, SR: Sharpe Ratio, IR: Information Ratio, TE:Tracking Error.

Table 3: Comparison of Excess Returns of The Fundamental Indexes With Respect To The Bist 100 Returns

\begin{tabular}{|c|c|c|c|c|c|c|c|c|c|c|c|c|}
\hline \multirow[b]{2}{*}{ PERIOD } & \multirow[b]{2}{*}{$A$} & \multirow[b]{2}{*}{$S$} & \multicolumn{6}{|c|}{ Indexes Weighted Annually per Fundamental Data } & \multicolumn{4}{|c|}{$\begin{array}{l}\text { Indexes Weighted per Five-year } \\
\text { Averaged Fundamental Data }\end{array}$} \\
\hline & & & NP & OP & BV & COMP & EW & $A$ & $\mathrm{~S}$ & NP & $\mathrm{OP}$ & BV \\
\hline 2001 & 0.147 & -0.032 & 0.172 & 0.152 & 0.126 & 0.113 & 0.014 & 0.138 & -0.088 & 0.161 & 0.133 & 0.113 \\
\hline 2002 & 0.023 & 0.037 & 0.094 & 0.091 & 0.064 & 0.062 & 0.198 & 0.025 & 0.022 & 0.075 & 0.074 & 0.069 \\
\hline 2003 & 0.179 & -0.073 & 0.019 & -0.032 & 0.065 & 0.031 & -0.221 & 0.148 & -0.103 & -0.019 & 0.021 & 0.037 \\
\hline 2004 & 0.039 & -0.117 & 0.117 & -0.051 & 0.032 & 0.004 & 0.017 & 0.091 & -0.099 & 0.157 & 0.023 & 0.028 \\
\hline 2005 & & -0.098 & 0.029 & & & & 0.020 & & & 0.021 & & 0.011 \\
\hline 2006 & & 0.026 & & & & & & & & & & 0.022 \\
\hline 2007 & -0.019 & -0.057 & -0.044 & -0.036 & -0.067 & -0.044 & -0.221 & $\mid-0.033$ & -0.072 & -0.047 & -0.058 & -0.071 \\
\hline 2008 & 0.019 & 0.008 & 0.027 & 0.023 & 0.018 & 0.019 & 0.001 & 0.015 & 0.004 & 0.024 & & 0.012 \\
\hline & & & & & & & & & & & & \\
\hline 2010 & 0.033 & 0.134 & 0.057 & 0.062 & 0.053 & 0.068 & 0.205 & 0.035 & 0.144 & 0.061 & 0.077 & 0.053 \\
\hline 2011 & -0.056 & 0.027 & 0.002 & 0.007 & -0.005 & -0.005 & 0.058 & $\mid-0.053$ & 0.021 & 0.003 & 0.016 & 0.002 \\
\hline 2012 & & & & & & & & & & & & 0.036 \\
\hline 2013 & -0.035 & & 0.014 & 0.009 & & 0.010 & 0.095 & $\mid-0.033$ & & & 0.007 & 0.019 \\
\hline 2014 & 0.036 & 0.041 & 0.001 & 0.052 & 0.037 & 0.033 & 0.027 & 0.043 & 0.055 & 0.013 & 0.058 & 0.043 \\
\hline 2015 & -0.008 & 0.097 & 0.028 & 0.007 & 0.021 & 0.029 & 0.148 & $\mid-0.006$ & 0.101 & 0.019 & 0.007 & 0.023 \\
\hline AAER & $0.053^{* *}$ & 0.024 & $0.051^{* * *}$ & $0.033^{* *}$ & $0.038^{* *}$ & $0.040^{* *}$ & 0.026 & $0.056^{* *}$ & 0.024 & $0.045^{* *}$ & $0.041^{* * *}$ & $0.038^{* *}$ \\
\hline T-STATS & 2.624 & 0.889 & 3.357 & 2.302 & 2.742 & 2.903 & 0.767 & 2.768 & 0.802 & 2.896 & 3.454 & 2.746 \\
\hline GAER & 0.051 & 0.020 & 0.050 & 0.032 & 0.037 & 0.039 & 0.017 & 0.054 & 0.019 & 0.043 & 0.040 & 0.037 \\
\hline BHER & 1.100 & 0.383 & 1.077 & 0.600 & 0.721 & 0.772 & 0.296 & 1.193 & 0.317 & 0.889 & 0.811 & 0.717 \\
\hline
\end{tabular}

AAER: Arithmetic Average of Excess Return, GAER: Geometric Average of Excess Return, BHER: Excess Return of Buy and Hold Strategy. 
Excess returns for the indexes with respect to the BIST-100 index are reported in Table 3. This table shows that all indexes bring in more gains annually on the average basis, meaning that they provide abnormal returns. However, the result of statistical tests as to the significance of the abnormal returns show that all indexes achieve statistically significant abnormal returns with respect to BIST 100 index except for the index based on sales with a $2.4 \%$ average annual return. An example to this finding is the index which is based on assets and reweighted annually, having statistically significant abnormal returns, on both geometrical (5.3\%) and arithmetic (5.1\%) terms with respect to cap-weighted BIST-100 index. Accordingly, an investor who places his/her funds into asset-weighted index in 2001 would end up with $110 \%$ more return than the BIST-100 index at the end of 15-year period. Similar results are also true for indexes based on both annual and 5-year average data with the book value and operating profit variables. Abnormal returns on book value and operating profit weighted indexes are 3.8\% and $3.3 \%$ annually.

The composite index, in which all other indexes which are based on companies' asset size, operating profit, book value, net profit and sales data have equal weights, has $4 \%$ and $3.9 \%$ higher arithmetic and geometric annual returns than BIST-100 index on average. Though the equal-weighted index results in a $2.6 \%$ abnormal return with respect to the BIST-100 index, this rate is not statistically significant. The index having the least tracking error is determined to be the one based on 5-year average operating profit data with the value 0.046 while equal-weighted index has the highest tracking error. Information ratios of indexes have been found to be greater than 0.5 except those based on asset size and sales. An information ratio higher than 0.5 is an indication of a good portfolio performance (Bacon, 2004).

\subsection{Findings on Index Performances Through CAPM and Fama-French Three Factor Model}

Basic statistics for the variables used in both CAPM and three factor model are presented in Table 4 and Table 5.

Descriptive statistics for the monthly return series of fundamental indexes, equal-weighted index and BIST100 for the period 2006-2015 are given in Table 4. Examining the averages of the monthly returns for the considered time period, we notice that all fundamental indexes have higher performances than BIST-100 index and the index based on asset size yields both the highest gain and the highest loss.

Stationarity tests for the return series have been implemented using Dickey and Fuller (1979) and Phillips and Peron (1988) unit root tests, results of which are reported in Table 5. Table 5 contains Augmented Dickey-Fuller (ADF) and Phillips-Perron (PP) test results for the monthly return series of indexes constructed. The stationarity condition is analyzed for the indexes and BIST100 where the corresponding test equation may include only a constant term or constant and trend terms together. Both cases probable in the test equation indicate that series are stationarity in their levels.

Table 4: Basic Statistics on Monthly Index Returns

\begin{tabular}{ccccccccccccccc}
\hline \hline & BIST & A & BV & EW & OP & COMP & NP & S & AA & ABV & AOP & ANP & AS \\
\hline \hline Mean & -0.002 & 0.001 & 0.001 & 0.009 & 0.001 & 0.002 & 0.001 & 0.003 & 0.001 & 0.001 & 0.001 & 0.001 & 0.003 \\
Med. & 0.002 & 0.000 & 0.004 & 0.010 & 0.004 & 0.006 & 0.002 & 0.009 & -0.002 & 0.006 & 0.009 & 0.004 & 0.008 \\
Max. & 0.219 & 0.326 & 0.246 & 0.193 & 0.254 & 0.268 & 0.247 & 0.229 & 0.318 & 0.248 & 0.264 & 0.238 & 0.242 \\
Min. & -0.248 & -0.274 & -0.248 & -0.152 & -0.246 & -0.266 & -0.241 & -0.258 & -0.252 & -0.250 & -0.274 & -0.246 & -0.258 \\
SS & 0.081 & 0.100 & 0.084 & 0.062 & 0.086 & 0.090 & 0.084 & 0.081 & 0.096 & 0.084 & 0.090 & 0.082 & 0.081 \\
N & 120 & 120 & 120 & 120 & 120 & 120 & 120 & 120 & 120 & 120 & 120 & 120 & 120 \\
\hline \hline
\end{tabular}

The table reports the basic statistics of the indexes/portfolios weighted on capitalizations ("BIST"), assets ("A"), book Value ("BV"), operating profit ("OP"), net profit ("NP"), sales ("S"), five-year average assets ("AA"), five-year average book value ("ABV"), five-year average operating profits ("AOP"), five-year average net profits ("ANP"), five-year average sales ("AS"), and the equally-weighted index ("EW"), the composite index ("COMP"). 
Table 5: Augmented Dickey Fuller and Phillips-Perron Stationarity Test Results for Monthly Return Series

\begin{tabular}{|c|c|c|c|c|c|c|c|c|}
\hline \multicolumn{6}{|c|}{ AUGMENTED DICKEY FULLER } & \multicolumn{3}{|c|}{ PHILLIPS-PERRON } \\
\hline & \multicolumn{2}{|r|}{ Constant } & \multicolumn{2}{|c|}{ Constant \& Trend } & \multicolumn{2}{|r|}{ Constant } & \multicolumn{2}{|c|}{ Constant \& Treno } \\
\hline & t-stat & p-value & t-stat & p-value & t-stat & p-value & t-stat & p-value \\
\hline A & -104.075 & 0.000 & -103.638 & 0.000 & -104.075 & 0.000 & -103.638 & 0.000 \\
\hline BV & -103.874 & 0.000 & -103.498 & 0.000 & -103.863 & 0.000 & -103.481 & 0.000 \\
\hline EW & -981.692 & 0.000 & -979.234 & 0.000 & -97.963 & 0.000 & -977.129 & 0.000 \\
\hline $\mathrm{OP}$ & -106.493 & 0.000 & -10.609 & 0.000 & -106.487 & 0.000 & -106.081 & 0.000 \\
\hline COMP & -104.107 & 0.000 & -103.724 & 0.000 & -104.094 & 0.000 & -103.706 & 0.000 \\
\hline$S$ & -103.399 & 0.000 & -103.085 & 0.000 & -103.748 & 0.000 & -103.425 & 0.000 \\
\hline NP & -105.986 & 0.000 & -105.583 & 0.000 & -105.973 & 0.000 & -105.566 & 0.000 \\
\hline AA & -106.765 & 0.000 & -106.333 & 0.000 & -106.765 & 0.000 & -106.333 & 0.000 \\
\hline ABV & -103.426 & 0.000 & -10.306 & 0.000 & -103.413 & 0.000 & -103.041 & 0.000 \\
\hline AOP & -103.057 & 0.000 & -102.648 & 0.000 & -10.304 & 0.000 & -102.629 & 0.000 \\
\hline ANP & -105.661 & 0.000 & -105.243 & 0.000 & -105.646 & 0.000 & -105.224 & 0.000 \\
\hline AS & -101.823 & 0.000 & -101.527 & 0.000 & -102.244 & 0.000 & -101.935 & 0.000 \\
\hline BIST & -106.068 & 0.000 & -105.708 & 0.000 & -106.134 & 0.000 & -105.773 & 0.000 \\
\hline
\end{tabular}

The table reports the stationarity test of the indexes' return weighted on capitalizations ("BIST"), assets (" $A$ "), book Value ("BV"), operating profit $\left(" O P^{\prime \prime}\right)$, net profit ("NP"), sales ("S"), five-year average assets ("A $A$ "), five-year average book value ("ABV"), five-year average operating profits $(" \mathrm{AOP} "$ "), five-year average net profits ("ANP"), five-year average sales ("AS"), and the equally-weighted index ("EW"), the composite index ("COMP").

Alpha and beta coefficients estimated through regression models are reported in Table 6. The highest alpha coefficient is obtained on the index where weighting is made in terms of asset size. This coefficient is found to be 0.012 and statistically significant at the $1 \%$ significance level. It is seen that alpha coefficients through CAPM on other indexes based on fundamental data are positive and significant when the Table is thoroughly reviewed.

This finding shows that returns on developed indexes are higher than that implied by CAPM. In other words, cap-weighted index, a typical example of which is the market index as analyzed here, is insufficient in explaining the returns provided by the other indexes and higher returns than predicted are possible to attain. Similar results are also obtained for the indexes based on past 5-year average data, i.e. positive and significant Jensen's alpha coefficients are estimated except for the index based on asset size. Comparable conclusions hold for composite and equal-weighted indexes. This research finding points out that in case investors construct their portfolios with simple rules, i.e. adjust portfolio weights through fundamental data, their returns, which take systematic risk into account would exceed cap-weighted index's return. The performances of fundamental indexes/portfolios are far better than the cap-weighted index in the long run.

Considering size and value factors into account, returns of developed indexes are also analyzed within the Fama-French three factor model framework and the results are reported in panel B of Table 6.

A general assessment of the results indicates that the Fama-French three factor model is also incapable of explaining the returns provided by fundamental indexes with index returns higher than those anticipated by the model. This is verified by positive and significant alpha coefficients found on all indexes except the index based on average assets. Moreover, coefficients for HML and SMB factors are not significant for some indexes, e.g. size and value coefficients on the composite index turn out to be insignificant. The finding implies there is no inclination towards big/small or value/growth stocks in selection mechanism related to the composite index. Similar findings on fundamental indexes as to their diminishing effects on HML and SMB factors are also reported by other studies, such as Mihm and Locarek-Junge (2009), Walkshausl and Lobe (2010) and De Moor et al. (2012). 
Table 6: Parameters of Regression Models Based on CAPM and three factor Model

\begin{tabular}{|c|c|c|c|c|c|c|c|c|}
\hline & & CAPM & & & & |REE FACT & & \\
\hline ENDEKS & $a$ & $\beta\left(R_{m t}-R_{f t}\right)$ & $\mathbf{R}^{2}$ & $a$ & $\beta\left(R_{m t}-R_{f t}\right)$ & (ס) HML & (p) SMB & $\mathbf{R}^{2}$ \\
\hline A & $\begin{array}{r}0.012 \\
(6.18)^{* *}\end{array}$ & $\begin{array}{r}1.202 \\
(48.03)^{* *}\end{array}$ & 0.951 & $\begin{array}{r}0.012 \\
(5.96)^{* *}\end{array}$ & $\begin{array}{r}1.168 \\
(43.72)^{* * *}\end{array}$ & $\begin{array}{r}0.089 \\
(2.11)^{*}\end{array}$ & $\begin{array}{l}-0.21709 \\
(-3.34)^{* *}\end{array}$ & 0.956 \\
\hline RY & 0.002 & 1.033 & 0.987 & 0.002 & 1.025 & 0.023 & -0.03586 & 0.987 \\
\hline DV & $(2.66)^{* *}$ & $(93.45)^{* * *}$ & & $(2.46)^{*}$ & $(83.46)^{* *}$ & -1.18 & $(-1.20)$ & \\
\hline D & 0.003 & 1.052 & 0.983 & 0.003 & 1.038 & 0.024 & -0.12763 & 0.985 \\
\hline 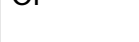 & $(2.91)^{* *}$ & $(83.56)^{* * *}$ & & $(2.61)^{*}$ & $(78.35)^{* *}$ & -1.15 & $(-3.96)^{* *}$ & \\
\hline NID & 0.003 & 1.03 & 0.984 & 0.002 & 1.018 & 0.021 & -0.11161 & 0.985 \\
\hline & $(2.82)^{* *}$ & $(84.05)^{* *}$ & & $(2.53)^{*}$ & $(77.90)^{* *}$ & -1.02 & $(-3.51)^{* *}$ & \\
\hline & 0.004 & 0.989 & 0.966 & 0.005 & 1.004 & -0.04497 & 0.075 & 0.967 \\
\hline S & $(3.22)^{* *}$ & $(58.02)^{* *}$ & & $(3.46)^{* *}$ & $(53.36)^{* *}$ & $(-1.51)$ & -1.64 & \\
\hline$C O M D$ & 0.004 & 1.111 & 0.985 & 0.004 & 1.108 & 0.003 & -0.03487 & 0.986 \\
\hline & $(4.15)^{* *}$ & $(89.25)^{* *}$ & & $(4.00)^{* *}$ & $(79.74)^{* *}$ & -0.15 & $(-1.03)$ & \\
\hline - & 0.01 & 0.563 & 0.531 & 0.011 & 0.608 & -0.22013 & -0.06652 & 0.567 \\
\hline & $(2.65)^{* *}$ & $(11.56)^{* * *}$ & & $(2.80)^{* *}$ & $(11.57)^{* *}$ & $(-2.64)^{* *}$ & $(-0.52)$ & \\
\hline & 0.003 & 1.164 & 0.963 & 0.002 & 1.129 & 0.092 & -0.21925 & 0.968 \\
\hline תו & -1.62 & $(55.60)^{* * *}$ & & -1.18 & $(51.83)^{* *}$ & $(2.66)^{* *}$ & $(-4.14)^{* *}$ & \\
\hline$\triangle P D$ & 0.002 & 1.032 & 0.986 & 0.002 & 1.027 & 0.016 & -0.01871 & 0.986 \\
\hline Rov & $(2.68)^{* *}$ & $(90.63)^{* * *}$ & & $(2.54)^{*}$ & $(80.69)^{* *}$ & -0.81 & $(-0.60)$ & \\
\hline ת & 0.003 & 1.098 & 0.976 & 0.003 & 1.086 & 0.019 & -0.12509 & 0.978 \\
\hline nor & $(2.31)^{*}$ & $(69.25)^{* * *}$ & & $(2.04)^{*}$ & $(63.40)^{* *}$ & -0.68 & $(-3.00)^{* *}$ & \\
\hline & 0.002 & 1.013 & 0.983 & 0.002 & 1.004 & 0.012 & -0.09377 & 0.985 \\
\hline RIVI & $(2.40)^{*}$ & $(83.56)^{* *}$ & & $(2.14)^{*}$ & $(76.62)^{* *}$ & -0.58 & $(-2.94)^{* *}$ & \\
\hline $1 \mathrm{c}$ & 0.005 & 0.993 & 0.966 & 0.005 & 1.007 & -0.04104 & 0.076 & 0.967 \\
\hline TJ & $(3.29)^{* *}$ & $(57.79)^{* * *}$ & & $(3.51)^{* *}$ & $(53.04)^{* *}$ & $(-1.36)$ & -1.65 & \\
\hline
\end{tabular}

NOTE: Values in parentheses show corresponding t statistics, * and ${ }^{* *}$ respectively indicate significance at $5 \%$ and $1 \%$ levels.

The table reports the regression results of CAPM and FF three factor CAPM. Dependent variables: indexes weighted on assets (" $A$ "), book value ("BV"), operating profit ("OP"), net profit ("NP"), sales ("S"), five-year average assets ("A $A^{\prime \prime)}$, five-year average book value ("ABV"), five-year average operating profits ("AOP"), five-year average net profits ("ANP"), five-year average sales ("AS"), and the equally-weighted index ("EW"), the composite index ("COMP").

\section{Conclusions}

Alternative index development strategies are widely debated in finance literature in terms of their capacity to provide higher returns than the cap-weighted indexes, which are accepted as benchmarks for performance measurement. In this context, indexation strategy based on fundamental data, which is among the class of such alternative index strategies, is analyzed in terms of performance in this paper. Indexes based on sales, asset size, book value, operating profit, and net profit variables and additionally composite and equal-weighted indexes are formed, their long-run returns are compared with the cap-weighted BIST-100 index. Comparison is carried out with both abnormal returns and their statistical significance, moreover, CAPM and three factor model are fitted for this purpose. Statistics for abnormal returns and the outputs of factor models indicate that index construction methodology based on fundamental data brings about higher value than the market portfolio. In this respect, portfolios based on fundamental data provide added value in comparison to the primary index of our country, namely BIST-100. The index weighted by asset size has provided the highest return among the fundamental indexes considered and constructed. We have determined that excess return, which signifies the difference in returns 
between fundamental indexes and the cap weighted index, is positive and significantly different from zero on all indexes developed except for the one based on sales. Except for the equal-weighted index, all fundamental indexes are identified to accommodate risk levels which are close to BIST-100 index (as measured by standard deviation) whereas Sharpe ratios, indicating the return obtained per unit of additional risk, are higher on all indexes than BIST-100.

Performances of indexes we develop are tested against benchmark models: CAPM and the three factor model. Positive and significant alpha coefficients are estimated with respect to both models on all indexes except the one based on 5-year average asset sizes.
This result indicates returns on the indexes developed are higher than that prescribed by CAPM and three factor model. Among the indexes composed, the index weighted per companies' asset size has the highest and significant alpha coefficient.

In conclusion, analiyses incorporating both excess returns and CAPM, FF three factor model clearly show that fundamental indexes developed in this study outperforms the cap-weighted index. The performances reached through indexes support the view that fundamental indexes are good alternatives for investors. With the alternative indexes formed by fundamental data, the investors will have an instrument which provides alternative investment opportunities. 


\section{References}

Almahdi, S. (2015). Smart Beta Portfolio Optimization. Journal of Mathematical Finance, (May), 202-211.

Amenc, N., Goltz, F., \& Martellini, L. (2013). Smart Beta 2.0. The Journal of Index Investing, (January), 1-37.

Amenc, N., Goltz, F., Sivasubramanian, S., \& Lodh, A. (2015). Robustness of Smart Beta Strategies. The Journal of Index Investing, 6(1), 17-38.

Arnott, R. D., \& Kose, E. (2014).What "Smart Beta" Means to Us. Research Affiliates Fundamentals, 1(212),1-5.

Arnott, R. D., \& West, J. M. (2006). Fundamental Indexes $^{\mathrm{TM}}$ : Current and Future Applications. ETFs and Indexing, 5(1), 111-121.

Arnott, R. D., Hsu, J. C., \& West, J. M. (2008). The Fundamental Index. John Wiley \& Sons, Inc.

Arnott, R. D., Hsu, J., \& Moore, P. (2005). Fundamental indexation. Financial Analysts Journal, 61(2), 83-99.

Bacon, C. R. (20M.S.). Practical Portfolio Performance Measurement and Attribution. (C. R. Bacon, Ed.). Hoboken, NJ, USA: John Wiley \& Sons, Inc.

Balatti, M., Brooks, C., \& Kappou, K. (2016). Fundamental indexing in the UK. SSRN Electronic Journal.

Blitz, D. C., \& Vliet, P. Van. (2007). The Volatility Effect : Lower Risk without Lower Return REPORT SERIES. Journal of Portfolio Management, 34(1), 102-113.

Blitz, D., \& Swinkels, L. (2008). Fundamental Indexation: An Active Value Strategy in Disguise. Journal of Asset Management, 9, 264-269.

Blitz, D., Grient, B. Van Der, \& Vliet, P. Van. (2010). Fundamental Indexation : Rebalancing Assumptions and Performance. Journal of Index Investing, 1(2), 82-88.

Branch, B., \& Cai, L. (2010). Fundamental Weighting. Journal of Applied Finance, 20(1), 47-60.

Cazalet, Z., Grison, P., \& Roncalli, T. (2013). The Smart Beta Indexing Puzzle. MPRA Paper, Working Pa, 1-26.

Chen, D., Dempsey, M., \& Lajbcygier, P. (2015). Is Fundamental Indexation able to time the market? Evidence from the Dow Jones Industrial Average and the Russell 1000. Journal of International Financial Markets, Institutions and Money, 37, 162-177.

De Moor, L., Liu, F., Sercu, P. M. F. A., \& Vinaimont, T. (2012). An Anatomy of Fundamental Indexing. SSRN Electronic Journal.

Denoiseux, V. (2014). Smart Beta: Building Low-Volatility Portfolios of ETFs. The Journal of Index Investing, 5(1), 127-135.
Dickey, D. A., \& Fuller, W. A. (1979). Distribution of the Estimators for Autoregressive Time Series with a Unit Root. Journal of the American Statistical Association, 74(366a), 427-431.

Estrada, J. (2008). Fundamental Indexation and International Diversification. The Journal of Portfolio Management, 34(3), 93-109.

Fama, E. F., \& French, K. R. (1993). Common risk factors in the returns on stocks and bonds. Journal of Financial Economics, 33(1), 3-56.

Fama, E. F., \& French, K. R. (1996). Multifactor Explanations of Asset Pricing Anomalies. The Journal of Finance, 51(1), 55-84.

Ferreira, R., \& Krige, J. . (2011). The application of fundamental indexing to the South African equity market for the period 1996 to 2009. Investment Analysts Journal, 40(73), 1-12.

Fisher, G. S., Shah, R., \& Titman, S. (2015). Decomposing Fundamental Indexation. The Journal of Index Investing, 6(3), 10-19.

Forbes, B., \& Basu, A. (2014). Does Fundamental Indexation Lead to Better Risk Adjusted Returns? New Evidence from Australian Securities Exchange. Accounting and Finance, 54(January 2013), 699-728.

Francis, J. C., Hessel, C., Wang, J., \& Zhang, G. (2010). Portfolios Weighted by Repurchase and Total Payout. The Journal of Portfolio Management, 36(4), 77-83.

Frino, A., \& Gallagher, D. R. (2001). Tracking S\&amp;P 500 Index Funds. The Journal of Portfolio Management, 28(1), 44-55.

Hansson, A., \& Vikström, G. (2010). Portfolio Strategies based on Fundamental Weighting: An Empirical Study of the Swedish Stock Market.

Harry Markowitz. (1952). Portfolio Selection. The Journal of Finance, 7(1), 77-91.

Haugen, R. A., \& Baker, N. L. (1991). The efficient market inefficiency of capitalization-weighted stock portfolios. Journal of Portfolio Management, 17(3), 35-40.

Hemminki, J., \& Puttonen, V. (2008). Fundamental indexation in Europe. Journal of Asset Management, 8(6), 401-405.

Houwer, R., \& Plantinga, A. (2009). Fundamental Indexing: An Analysis of the Returns, Risks and Costs of Applying the Strategy. SSRN Electronic Journal.

Hsieh, H. H. (2013). Unlocking the secrets of fundamental indexes: Size effect or value effect? Evidence from 
emerging stock markets. Investment Management and Financial Innovations, 10(4), 48-63.

Hsieh, H. H., \& Engel, J. S. (2014). Application of fundamental indexation for South African equities.

Hsieh, H. H., Hodnett, K., \& Rensburg, P. van. (2012). Fundamental indexation for global equities: Does firm size matter? Journal of Applied Business Research, 28(1), 105-114.

Hsu, J. (2014). Value Investing: Smart Beta versus Style Indexes. The Journal of Index Investing, 5(1), 121-126.

Hsu, J. C. (2004). Cap-Weighted Portfolios Are Sub-optimal Portfolios. SSRN Electronic Journal, Working $\mathrm{Pa}, 1-22$.

Hsu, J. C., \& Campollo, C. (2006). New Frontiers in Index Investing. Journal of Indexes, (January/February), 32-58.

Hsu, J. C., Li, F., \& Kalesnik, V. (2010). Does Valuation-Indifferent Indexing Work for the Real Estate Market? The Journal of Investing, 19(3), 72-79.

Hsu, J., Kalesnik, V., \& Viswanathan, V. (2015). A Framework for Assessing Vulnerability. The Journal of Index Investing, 6(1), 89-97.

Jacobs, B. I., \& Levy, K. N. (2014). Smart Beta versus Smart Alpha. The Journal of Portfolio Management, 1-11.

Jun, D., \& Malkiel, B. G. (2008). New paradigms in stock market indexing. European Financial Management, $14(1), 118-126$.

Kahn, R. N., \& Lemmon, M. (2015). Smart Beta:The Owner's Manual. The Journal of Portfolio Management, 76-83.

Kaiser, L. (2014). Categorical Evaluation of Alternative Index Weighting Schemes. SSRN Electronic Journal.

Lajbcygier, P., \& Sojka, J. (2015). The viability of alternative indexation when including all costs. International Review of Financial Analysis, 38, 109-141.

Maillard, S., Roncalli, T., Teiletche, J., Bouyé, E., Bruder, B., Michel, T., ... Weisang, G. (2010). On the properties of equally-weighted risk contributions portfolios. The Journal of Portfolio Management, 36(4), 60-70.

Malkiel, G. B. (2014). Is Smart Beta Really Smart? Journal of Portfolio Management, 40(5), 127-134.

Mar, J., Bird, R., Casavecchia, L., \& Yeung, D. (2009). Fundamental Indexation: An Australian Investigation. Australian Journal of Management, 34(1), 1-20.

Marchioni, U., Antropova, S., \& McNaught, C. (2015). Smart Beta Strategies as Outcome-Oriented Solutions in the Equity Space. The Journal of Index Investing, 6(1), 65-78.
McQuarrie, E. F. (2008). Fundamentally Indexed or Fundamentally Misconceived : Locating the Source of RAFI Outperformance. The Journal of Investing, 17(4), 29-37.

Meziani, S. (2014). Smart Beta ETFs: A Bird's-Eye View of the Market and Analysis of Its Performance Trends. The Journal of Index Investing, 1-20.

Mihm, M., \& Locarek-junge, H. (2019). Empirical Examination of Fundamental Indexation in the German Market. (A. Fink, B. Lausen, W. Seidel, \& A. Ultsch, Ed.), Studies in Classification, Data Analysis, and Knowledge Organization. Berlin, Heidelberg: Springer Berlin Heidelberg.

Miziołek, T., \& Zaremba, A. (2017). Fundamental Indexation in European Emerging Markets. Romanian Journal of Economic Forecasting, 10(1), 23-37.

Montier, J. (2014). No Silver Bullets in Investing (Just Old Snake Oil in New Bottles). The Journal of Index Investing, 5(1), 77-96.

Naylor, M., \& Dai, W. (2016). The Application of Fundamental Indexation to the BRICs.

Phillips, P. C. B., \& Perron, P. (1988). Testing for a unit root in time series regression. Biometrika, 75(2), 335-346.

Plyakha, Y., Uppal, R., \& Vilkov, G. (2016). Why Does an Equal-Weighted Portfolio Outperform Value- and Price-Weighted Portfolios? SSRN Electronic Journal, Working $\mathrm{Pa}$ (March), 1-36.

Podkaminer, E. (2015). The Education of Beta: Can Alternative Indexes Make Your Portfolio Smarter? Journal of Investing, 24(2), 7-34.

Roncalli, T. (2014). Introduction to Risk Parity and Budgeting. Chapman and Hall/CRC. Chapman \& Hall/CRC.

Ross, S. A. (1977). The Capital Asset Pricing Model (Capm), Short-Sale Restrictions And Related Issues. The Journal of Finance, 32(1), 177-183.

Sharpe, W. F. (1977). Capital Asset Prices: A Theory of Market Equilibrium Under Conditions of Risk. The Journal of Finance, 19(3), 425-442.

Stotz, O., Wanzenried, G., \& Döhnert, K. (2010). Do fundamental indexes produce higher risk-adjusted returns than market cap indexes? Evidence for European stock markets. Financial Markets and Portfolio Management, 24(3), 219-243.

Treynor, J. (2005). Why Market-Valuation-Indifferent Indexing Works. Financial Analysts Journal, 61(5), 65-69.

Walkshäusl, C., \& Lobe, S. (2010). Fundamental indexing around the world. Review of Financial Economics, 19(3), 117-127. 